\title{
Comparative Morphological Study of Os Coxae and Synsacrum Bones of Common Hawk Cukoo (Hierococcyx varius) and Yellow Billed Babbler (Argya affinis)
}

\author{
B. Supriya ${ }^{1 *}$, M. L. Bharath Kumar ${ }^{2}$ and K. V. Jamuna ${ }^{3}$ \\ ${ }^{1}$ Department of Veterinary Anatomy, College of Veterinary Science, Tirupati, A.P, India \\ ${ }^{2}$ Department of TVCC, Veterinary College, Hebbal, Banglore, Karnataka, India \\ ${ }^{3}$ Department of Veterinary Anatomy, Veterinary College, Hebbal, Banglore, Karnataka, India \\ *Corresponding author
}

\section{A B S T R A C T}

\begin{tabular}{|c|}
\hline Keywords \\
\hline $\begin{array}{l}\text { Oscoxae, Common } \\
\text { hawk cukoo, } \\
\text { Yellow billed } \\
\text { babbler, Synsacrum }\end{array}$ \\
\hline Article Info \\
\hline $\begin{array}{l}\text { Accepted: } \\
12 \text { September } 2020 \\
\text { Available Online: } \\
10 \text { October } 2020\end{array}$ \\
\hline
\end{tabular}

The present study aimed to throw light upon the os coxae and synsacrum of common hawk cukoo and yellow billed babbler. The pelvic girdle was formed by ilium, ischium and pubis in both the birds. The ratio of preacetabular to postacetabular part of ilium was 1:1 and 3:2 in common hawk cukoo and yellow billed babbler respectively. The lateral border of post acetabular part of ilium showed a prominent projection behind the foramen ischiadicum in yellow billed babbler and it was absent in common hawk cukoo. A small pectineal process was noticed at the anterior end of the pubis below the level of acetabulum in yellow billed babbler and it was absent in common hawk cukoo. The synsacrum of common hawk cukoo and yellow billed babbler consisted of 11 and 15 vertebrae respectively. The differences in osteological features of os coxae and synsacrum may be due to their habits.

\section{Introduction}

Many of the morphological features of birds were considered to be adaptations to the habitat. The arched shape of the pelvic bones enables birds to carry the weight of the body, which was usually light, in the bipedal standing posture (King and Mc Lelland., 1975). The common hawk cukoo was the resident of Indian subcontinent. It was arboreal and rarely descends to the ground. The yellow billed babbler was endemic to southern India. It was sedentary with weak flight. The behaviour associated with a specific habitat was favoured by a certain morphological feature and the observed morphology of a species should be some trade-off between the different selection pressures acting on the birds.

Literature pertaining to sternum (Botlagunta et al., 2019) and fore limb bones (Supriya et al., 2019) of common hawk cukoo and yellow billed babbler were only available. Whereas, literature pertaining to oscoxae and synsacrum of the common hawk cukoo and 
yellow billed babbler was not available; hence, the present study was undertaken.

\section{Materials and Methods}

The carcass of common hawk cukoo and yellow billed babbler were collected and the bones were procured by natural maceration by anaerobic microorganisms. The oscoxae and sysacrum was separated and kept in water added with $10 \%$ washing soda $\left(\mathrm{Na}_{2} \mathrm{Co}_{3}\right)$ for three days (Duzler et al., 2006). Then bones were washed in tap water and dried under room temperature. The morphology of bones was studied and the length of the long bones was measured by using vernier calipers.

\section{Results and Discussion}

The os-coxae of common hawk cukoo and yellow billed babbler consisted of three bones namely the ilium, ischium and pubis (Fig. 15) as also reported in ostrich (Tamilselvan et al., 2015) and peacock, peahen (Deshmukh et al., 2016). The rhomboid shape lumbosacral mass lodged in the space between the pelvic bones (Mc Lelland, 1990). This is very much needed in flying birds to maintain posture during flying (Ilulis and pulea, 2011).

The ilium was narrow, elongated and consisted of pre-acetabular and postacetabular parts as in domestic birds (Nickel et al., 1977) and both parts were joined with lumbo-sacral mass which was also observed in Japanese quail (Mehta et al., 2014), ostrich (Tamilselvan et al., 2015), guinea fowl and pigeon (Lavanya et al., 2017), Indian eagle owl (Sarma et al., 2018) and crested serpent eagle and brown wood owl (Keneisenuo et al., 2019).

The ratio of preacetabular to postacetabular part of ilium was $1: 1$ and 3:2 in common hawk cukoo and yellow billed babbler respectively. The ilium of the common hawk cukoo completely fused with lumbosacral mass to form a quadrilateral roof of the pelvis and the concavity of dorsal surface of preacetabular part was less (Fig. 3). Mehta $e t$ al., (2014) also mentioned that the ilium consisted of pre and post acetabular parts and were fused with lumbosacral mass in Japanese quail. The dorsal surface of pre acetabular part was deeply concave in yellow billed babbler compared to common hawk cukoo (Fig. 3, 4).

The ventral surface of posterior third of preacetabular part and post acetabular part was excavated to form renal fossa like in domestic birds (Nickel et al., 1977). The renal fossa was oval in common hawk cukoo (Fig. 1) and it was elongated in yellow billed babbler (Fig. 2). The lateral border of post acetabular part of ilium showed a prominent projection behind the foramen ischiadicum in yellow billed babbler and it was absent in common hawk cukoo (Fig. 4, 5). The presence of similar projection also observed in Japanese quail (Mehta et al., 2014).

Ischium bone was triangular, and its thick anterior angle participated in the formation of acetabulum in both the species under study. As reported by Nickel et al., (1977) in domestic fowl, the dorsal border of ischium along with the lateral border of post acetabular part of ilium formed the sciatic foramen posterior to the acetabulum in both the species. The ventral border of ischium in both the birds under study was convex and the obturator foramen was formed by the ventral border of ischium behind acetabulum and middle part of pubis (Fig. 1, 2 and 5) like in Japanese quail (Mehta et al., 2014). Posterior border of the ischium was free. The posterior border of ischium in common hawk cukoo was convex and in the yellow billed babbler it was concave in the upper part and convex in the lower part (Fig. 4, 5). The caudal border of spotted billed pelican was cocave 
(Satyamoorthy et al., 2012). In case of pea hens (Sreeranjani et al., 2012) and Japanese quail (Mehta et al., 2014) the ventral end of the caudal border formed angulus ischiadicus which was blunt and not fused with pubis.

Fig. 1 and 2

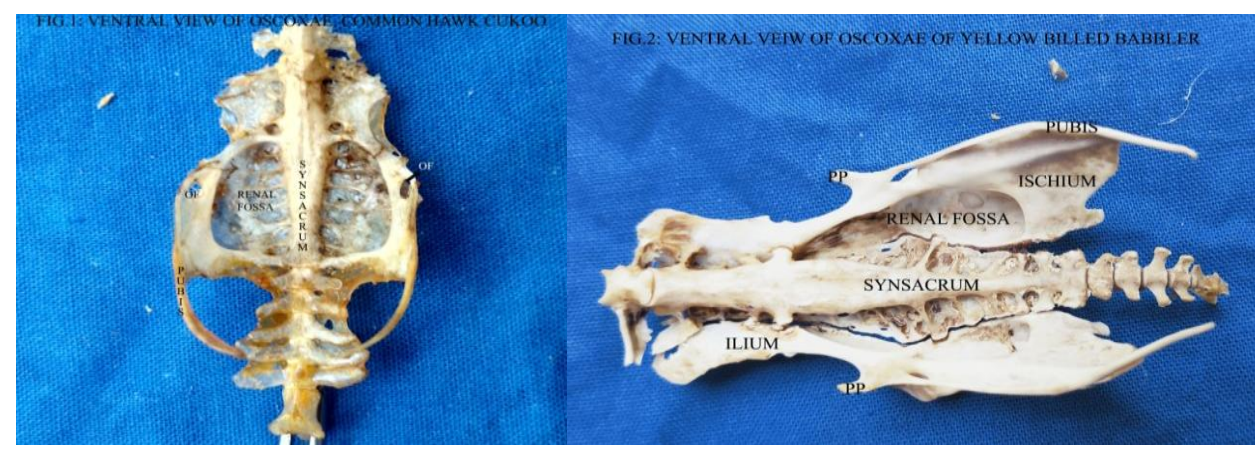

Fig.2 and 4

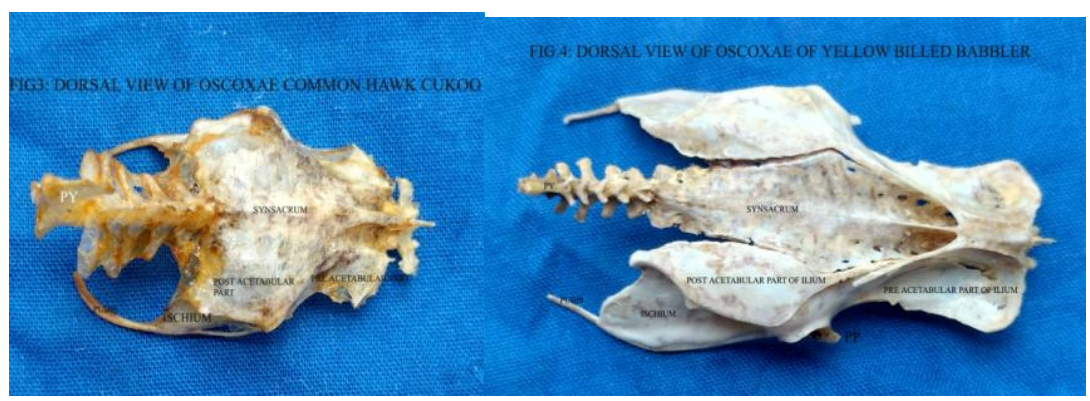

Fig.5

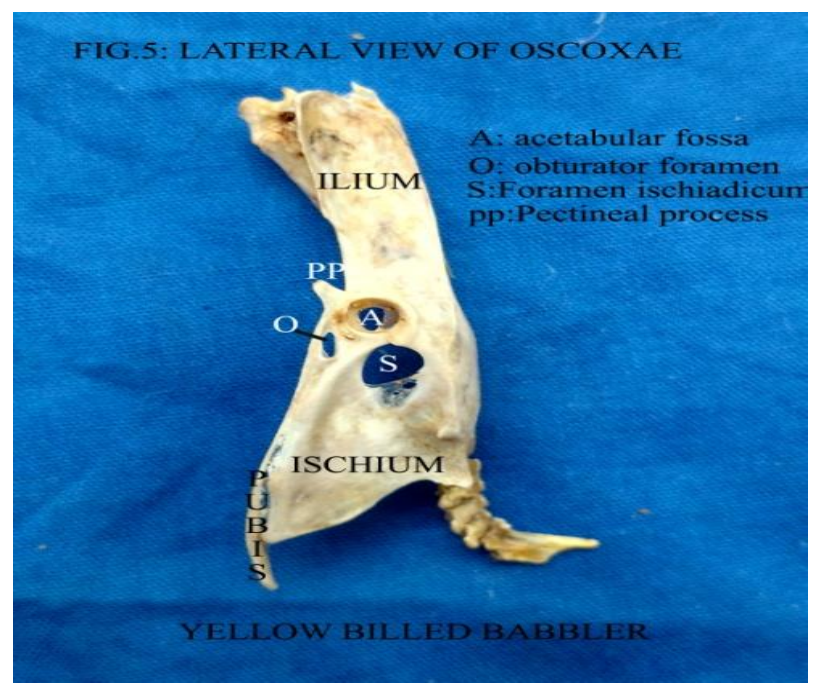

The pubis was thin bent rod like bone, attached to ischium and projected beyond it
(Fig. 1 and 2). A small pectineal process was noticed at the anterior end of the pubis below 
the level of acetabulum in yellow billed babbler (Fig. 5) as noted in guinea fowl (Lavanya et al., 2017) peahen (Sreeranjini et al., 2011) and domestic fowl (Nickel et al., 1977) and there was no pectineal process seen in common hawk cukoo as reported by and Sarma et al., (2018) in Indian eagle owl, Lavanya et al., (2017) in pigeon and Mehta et al., (2014) in Japanese quail. In both the species under study pubis also participated in the formation of acetabulum like in pegion (Ilulis and Pulea, 2011), in pea hens (Sreeranjani et al., 2011) and in spotted billed pelican (Satyamoorthy et al., 2012). Contrary to this in Japanese quail pubis bone was not participated in the formation of acetabulum (Mehta et al., 2014).

In both the species, the acetabulum was perforated and circular in outline (Fig. 5) like in peacock and peahen (Deshmukh et al., 2016). A large triangular shaped antitrochanter was observed in the dorso-caudal aspect of the in both the species under study as described in Indian eagle owl (Sarma et al., 2018). The facet noticed on the antitrochanter is for articulation with trochanter major of the femur as mentioned in cattle erget (Resk, 2015), spot-billed pelicans (Sathyamoorthy et al., 2012), guinea fowl and pigeon (Lavanya et al., 2017).

The synsacrum composed of last thoracic vertebrae, lumbosacral mass and the first coccygeal vertebra (Fig. 1 and 2). The synsacrum of common hawk cukoo and yellow billed babbler consisted of 11 and 15 vertebrae respectively. The supraspinous process of last thoracic and those of first few lumbar vertebrae interposed between the dorsal border of pre acetabular part of ilium. Thus the supraspinous processes of synsacrum divide the cranalis ilioneuralis as in Japanese quail (Mehta et al., 2014).

In conclusion the comparative anatomy of os coxae in common hawk cukoo and yellow billed babbler revealed that the os coxae was formed by ilium, ischium and pubis, and it showed minor differences between two species. It is concluded that the differences in osteological features of os coxae and synsacrum may be due to its flying and terrestrial habits.

\section{References}

Botlagunta, S., Girish, M. H., and Jamuna, K. V. 2019. Gross morphological studies on the sternum of common hawk cukoo (Hierococcyx varius) and yellow billed babbler (Argya affinis) The Pharma Innovation Journal, 8(12): 272-274.

Choudhary, O. P., Arya, R. S., Kalita, P. C., Doley, P. J., Rajkhowa, T. K., and Kalita, A. 2019. Comparative Gross Morphological Studies on the OsCoxae of Crested Serpent Eagle (Spilornis cheela) and Brown Wood Owl (Strix leptogrammica). Journal of Animal Research, 9(3), 439-442.

Deshmukh, S. K., Karmore, S. K., Gupta, S. K., Kodape, S., and Prakash, R. 2016. Comparative biometrical studies on the os-coxae and synsacrum of peacock and peahen. Vet. Pract, 17(1), 41-42.

Düzler, A., Özgel, Ö., and Dursun, N. 2006. Morphometric analysis of the sternum in avian species. Turkish Journal of Veterinary and Animal Sciences, 30(3), 311-314.

Iuliis, G., and Pulerà, D. (2019). The dissection of vertebrates. Academic Press.

Lavanya, C., Jayachitra, S., Iniya, K., and Balasundaram, K. 2017. Comparative anatomy of os coxae in guinea fowl and

Pigeon.

Int.J.Curr.Microbiol.App.Sci, $\quad$ 6(9): 3655-3659.

McLelland, J. (1990). A colour atlas of avian anatomy. Wolfe Medical Publications Ltd.

Mehta, S., Guha, K., Shalini, S., and Kumar, 
C. 2014. Gross Anatomical Studies on the Os-coxae and Synsacrum of Japanese Quail (Coturnix coturnix japonica). Indian Journal of Veterinary Anatomy, 26(2). 126-127.

Nickel, R., Schummer, A., Seiferle, E., Siller, W. G., and Wight, P. A. L. 1977. Anatomy of the Domestic Birds; Verlag Paul Parey. Berlin, Hamburg.

Resk, H. M. 2015. Anatomical investigation on the appendicular skeleton of the cattle egret (Bubulcus ibis) J. Exp. Clin. Anat, 14(1), 5-12.

Sarma, K., Suri, S., and Sasan, J. S. 2018. Gross anatomical studies on os coxae of Indian Eagle owl (Bubo bengalensis). Exploratory Animal and Medical Research, 2, 208-210.

Sathyamoorthy, O. R., Thirumurugan, R., Kumar, K. S., and Jayathangaraj, M. G. 2012. Gross morphological studies on the pelvic girdle of spot-billed pelicans (Pelecanus philippensis). Indian
Journal of Veterinary Anatomy, 24(2). Sreeranjini, A. R., Ashok, N., Indu, V. R., Lucy, K. M., Syam, K. V., Chungath, J. J., and Harshan, K. R. 2011. Morphological studies on the pelvic girdle of a peahen (Pavo cristatus). Journal of Indian Veterinary Association, Kerala (JIVA), 9(3), 4648.

Supriya, B., K. Manjunatha and Jamuna, K. V. 2019. Comparative Morphological Study of Pectoral Limb Bones of Common Hawk Cukoo (Hierococcyx varius) and Yellow Billed Babbler (Argya affinis). Int.J.Curr.Microbiol. App.Sci. 8(12): 1780-1784.

Tamilselvan, S., Iniyah, K., Jayachitra, S., Sivagnanam, S., Balasundaram, K., and Lavanya, C. 2015. Gross anatomy of os coxae of ostrich (Struthio camellus). Int.J.Curr.Microbiol.App.Sci, 4(4):201205

\section{How to cite this article:}

Supriya, B., M. L. Bharath Kumar and Jamuna, K. V. 2020. Comparative Morphological Study of Os Coxae and Synsacrum Bones of Common Hawk Cukoo (Hierococcyx varius) and Yellow Billed Babbler (Argya affinis). Int.J.Curr.Microbiol.App.Sci. 9(10): 1284-1288. doi: https://doi.org/10.20546/ijcmas.2020.910.154 